\title{
DEVELOPMENT A MACHINE FOR DRINKING WATER PROCESSED WITH HYBRID GREEN ENERGY FOR REMOVED AREAS IN VIETNAM
}

\author{
TUAN PHAN ANH \& TAN NGUYEN MINH
}

Hanoi University of Science and Technology, Hanoi, Vietnam

\begin{abstract}
This paper mentions to a research and development a Machine for Drinking Water Processed (MDWP) with hybrid green energy for removed area in Vietnam. The machine is designed for processing the qualitative drinking water by hybrid wind and solar energies. This machine is designed for people who live in removed areas where the national electrical grid is does not provided. There machine uses two disinfection technology for drinking water process. Firstly, raw water from drilled wells will be disinfected by electrolysis cell (using MOX electrodes) treatment technology. Secondly, the preprocessed water is disinfected by ultraviolet (UV) treatment technology. Power for water process is provided by a hybrid green energy system, wind and solar energies. A Mixture Axis Wind Turbine (MAWT) is designed and manufactured for converting wind energy to electric supply for the machine. Solar panels are integrated to the wind energy unit for being hybrid green energy system. Prototypes of MDWP have made and now testing for drinking water processed in a removed area in Vietnam.

KEYWORDS: Drinking Water, Process, Disinfection, Green Energy, Removed Area
\end{abstract}

Received: Jun 10, 2020; Accepted: Jun 30, 2020; Published: Aug 01, 2020; Paper Id.: IJMPERDJUN2020556

\section{INTRODUCTION}

It could be said that safety drinking water is very important for our live. In the total picture of water needed in Vietnam, there are about $20 \%$ of its population has not yet access to clean and safety water for their daily life. There are currently about 17.2 million Vietnamese people, equivalent to around $21.5 \%$ of the total population, who are using direct water from drilled wells that has not been done water treatment.

In Vietnam, as well in other emerging and developing countries such as in ASEAN, there are considerable problems to realize a safe drinking water supply in rural, mountain, island and removed areas. Such regions are characterized by insufficient infrastructure, e.g. there are often no drinking water connection, no wastewater treatment and an unreliable energy supply. As a main problem in water quality, the available surface water is often polluted with germs and coliforms. For an efficient drinking water treatment or disinfection at present and in the medium-term, the needed equipment and requirements for a comprehensive improvement of water quality are not available (e.g., missing chemicals, financial resources, energy capacities). With regard to germ load problem, there are additional difficulties due to microbial recontamination, as well as biofilm formation during water storage at the given climate conditions.

Due to the rapid economic development in Vietnam, river water quality has been affected along with an increased concentration of various toxins in the water. The surface water in the rivers is locally polluted by organic pollutants such as oil waste and solids. There is also pollution from untreated waste water released by industries and agriculture and daily activities. The geography and topography of Vietnam also makes the country susceptible to 
natural hazards such as typhoons, storms, floods and drought. This then leads to a multitude of problems such as water pollution and waterborne diseases along with an impact on agricultural lands and livestock. Both the environmental pollution in these river basins and natural disasters affects the nation's public health. The Ministry of Natural Resources and Environment state that almost $80 \%$ of the diseases in Vietnam are caused by polluted water. There are many cases of cholera, typhoid, dysentery and malaria each year in the country $[1,2,3]$.

Results of a survey on rural sanitation conducted by the Ministry of Health $(\mathrm{MoH})$ in 2007 showed that the structure of main drinking and domestic water sources in rural households is as follows: $33.1 \%$ borehole, $31.2 \%$ shallow well, $1.8 \%$ rainwater harvest, $11.7 \%$ piped water, $7.5 \%$ spring water, $11 \%$ river, pond and lake water and $3.7 \%$ other water sources. Only $25.1 \%$ of the total 2,958 water samples taken from domestic water sources of rural households from 8 ecological regions meet microbiological standards [4].

The rate of rural people having access to domestic water meeting Vietnamese standard QCVN 02:2009/BYT is $40 \% .80 \%$ of elementary and secondary schools and kindergartens have drinking water and latrines. $48 \%$ of rural markets have drinking water and sanitation works [5].

As a developing country, many removed areas in Vietnam do not have national electric grids. Those areas are also lack of safety drinking water resource. Development a machine for drinking water processed with green energy for removed areas is presented in this paper.

\section{TECHNOLOGIES}

\section{Electrochemical Disinfection}

An electrochemical water disinfection system is a device that eradicates microorganisms by using an electric current passed through the water under treatment by means of suitable electrodes. Figure 1 show that the electrochemical disinfection diagrams and device of the MDWP.

In the electrochemical water disinfection process, at the phase boundary between the electrodes and the water, the electric current leads to the electrochemical production of disinfecting species from the water itself or from species dissolved in the water. In our design of the MDWP, the electric current leads to the electrochemical production of disinfecting by chloride that oxidised to free chlorine. The electrochemical water disinfection device uses 24 VDC (volts DC) source. The electrodes are exchanged every delay set time period. The delay set time for changing the electrodes is depending on the density of natural chlorine of the raw input water. Therefore, it is needed to test water impurity before setting the delay time for exchanging the electrodes. 

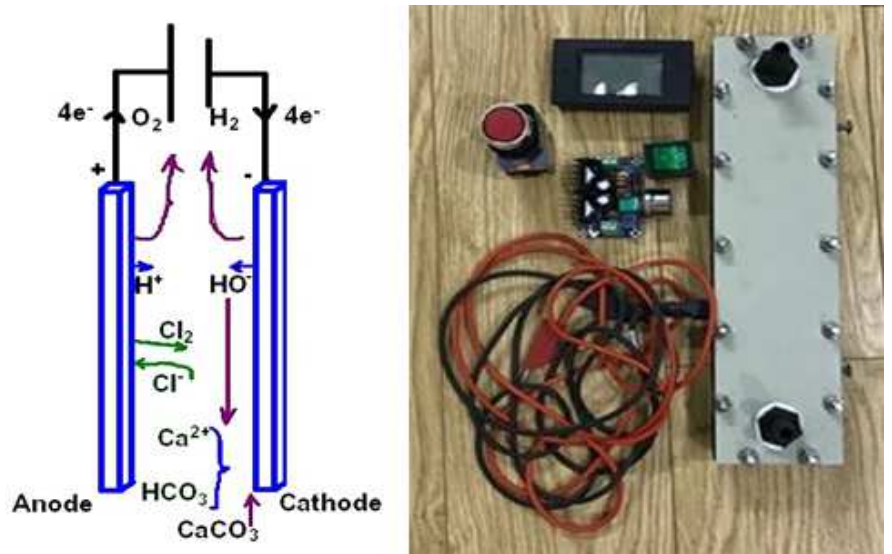

Figure 1: Electrochemical Disinfection Diagram and Device of the MDWP.

For disinfection, free chlorine will be created by the following chemical reaction

$$
\mathrm{Cl}_{2}+\mathrm{H}_{2} \mathrm{O} \Leftrightarrow \mathrm{H}^{+}+\mathrm{Cl}^{-}+\mathrm{HOCl}
$$

\section{UV Disinfection}

The ultraviolet (UV) treatment process is an extremely quick physical process. Ultraviolet light mutates and degrades DNA of organism. DNA is the part of the cell that gives an organism its instructions on how to function and reproduce. UV disinfection technology has been investigated by several authors. Bergmann did a research study on drinking water disinfection by direct electrolysis - state of the art [6]. Song et al. studied an application of ultraviolet light-emitting diodes (UV-LEDs) for water disinfection [7].

In the UV disinfection process, water is purified as it runs through a stainless steel pipe chamber that contains a special UV - producing lamp in center. As the water flows past the lamp, the microbes in the water receive a lethal dose of UV. The water is then safe to drink. However, different organisms require different levels of UV energy to disrupt their DNA. This energy level is known as a UV dose. In our design of the MDWP, the UV lamp has maximum power of $25 \mathrm{~W}$. The lamp uses 24VDC source. To identify the level of energy for supporting to the UV lamp, a sensitive sensor for checking organism density and water impurity is setting up at the stainless steel pipe chamber. An UV control unit that uses the sensitive sensor data for analysis and control the power to the lamp is putted in a plastic box. Figure 2 shows the UV disinfection diagram and device of the MDWP.
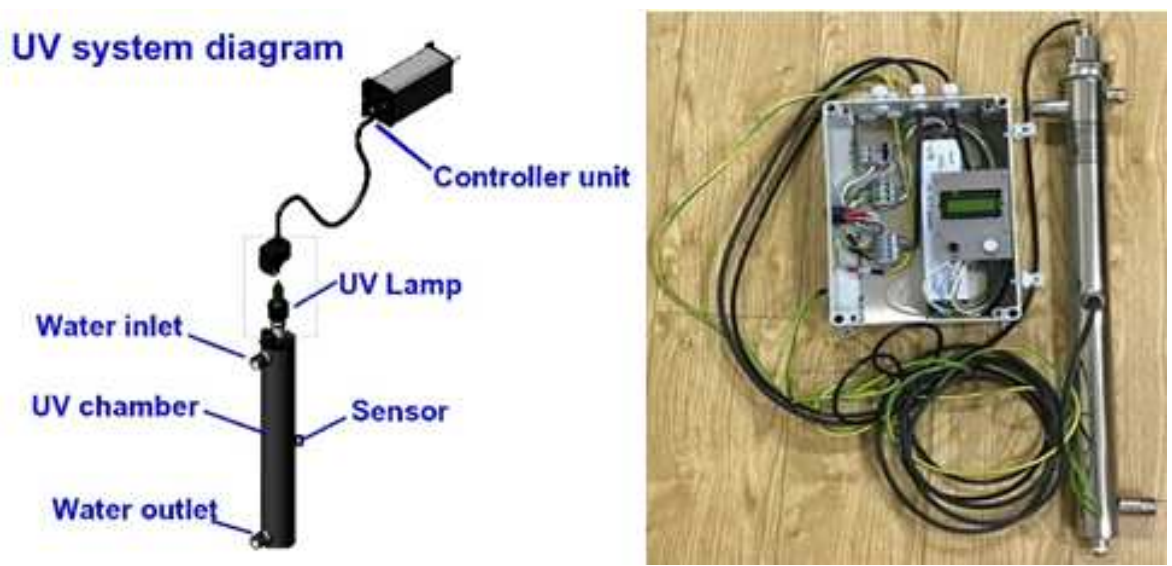

Figure 2: UV Disinfection Diagram and Device of the MDWP. 


\section{MAWT Wind Turbine}

For supporting electricity to the MDWP, in this design we use a mixture axis wind turbine. The turbine blade area for converting electricity of the wind turbine could be seen in Figure.3. The converting power of a vertical wind turbine could be estimated as [8]:

$$
\mathrm{P}=\mathrm{C}_{\mathrm{p}} \rho \mathrm{HDv} v^{3}
$$

Where, $\mathrm{Cp}$ is power coefficient of the wind turbine. This coefficient is depended on type of wind turbine and manufacturing technology. In our design, the Cp coefficient of the wind turbine is around 0.3.

$\rho$ is density of air in wind,

$\mathrm{H}$ is high of blades of the turbine,

$\mathrm{D}$ is diameter of the blade disk of the turbine,

$\mathrm{v}$ is wind velocity.

The output power chart of the wind turbine generator is shown in Figure. 4.

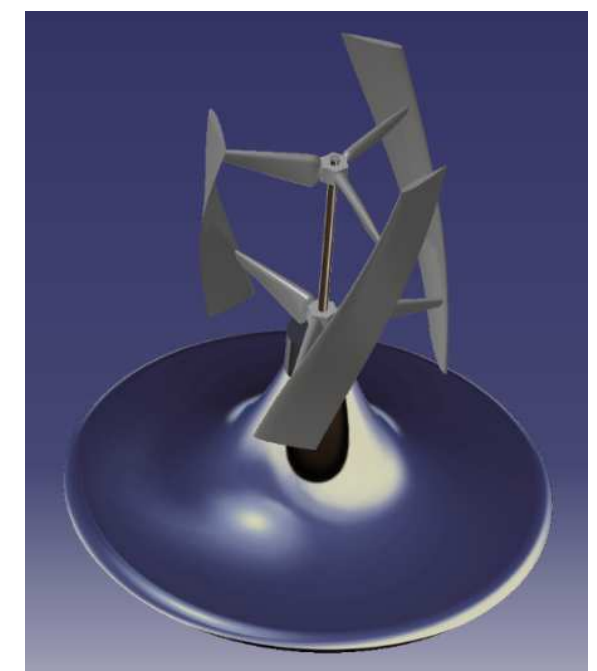

Figure 3: MAWT Wind Turbine.

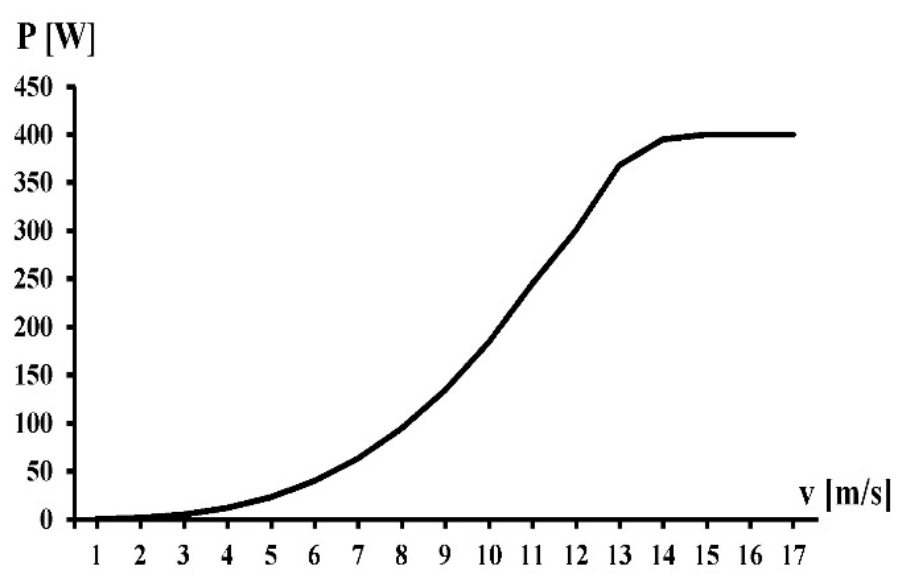

Figure.4: Output Wind Turbine Power Chart. 
The output power chart shows that the wind turbine will work well with wind velocity from $6-14 \mathrm{~m} / \mathrm{s}$. When the air velocity is stronger than $14 \mathrm{~m} / \mathrm{s}$, the output power of the wind turbine could not increase because the limitation of the maximum output power of the electrical generator. When the wind velocity is too high, the wind turbine will start its brake system to protect itself.

\section{Solar Energy}

In this MDWP, solar panels are integrated to the wind energy unit for being a hybrid green energy system. They are two 50W solar panels. This solar panels are purchased in market, not designed by our group. Figure. 5 shows the solar panels.

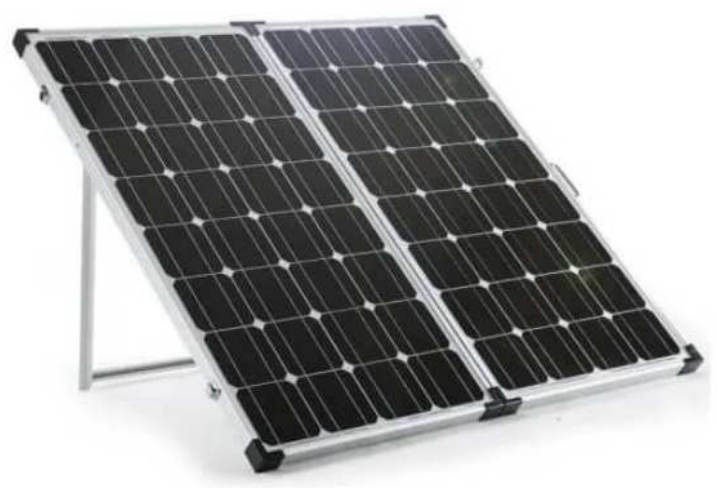

Figure 5: Solar Panels of the MDWP.

\section{Hybrid Energy System}

Energy for the MDWP is provided by a hybrid green energy system, wind and solar energies. It is a hybrid energy system with 400W wind energy and 100W solar energy. To control the supply energies for the MDWP, an energy charging and controlling unit is used. The unit is shown in Figure. 6.

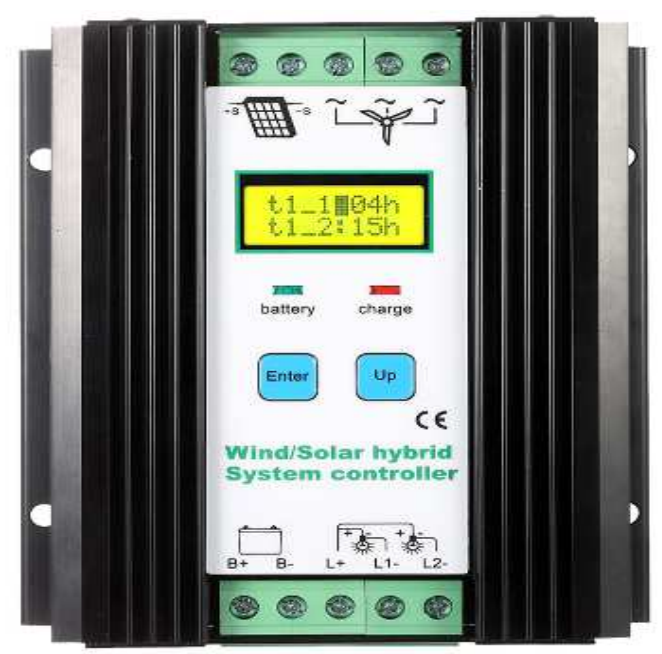

Figure 6: Charging and Controlling Unit for Hybrid Energy System.

\section{RESULTS AND DISCUSSION}

In this study, a machine for drinking water processed with hybrid green energy has developed. The machine working diagram is shown in Figure. 7. 


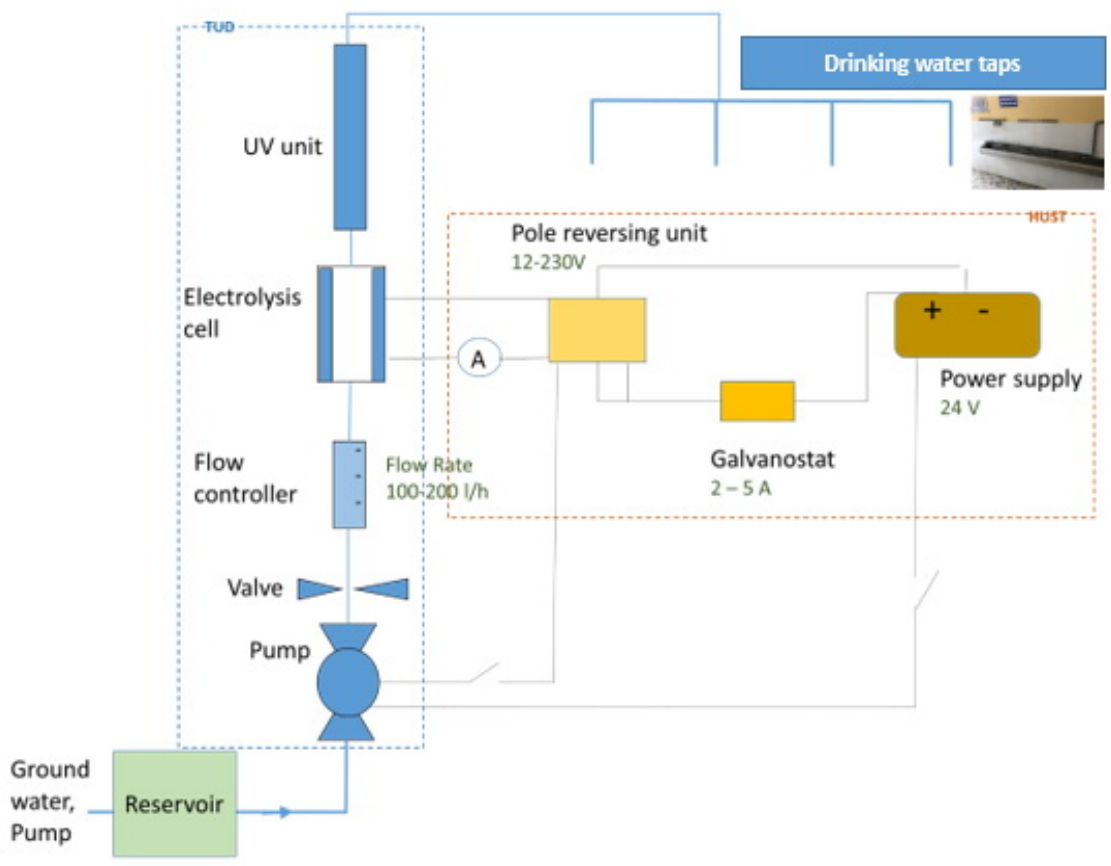

Figure 7: MDWP Working Diagram.

A prototype of the MDWP is made. With this design, raw water underground from drilled well is pumped directly and solve for being safety drinking water by the MDWP. Raw water goes into the cell electrochemical device for the first disinfection. After disinfecting by cell electrochemical device, water goes into the UV device for the second disinfection. After doing disinfections, water goes to the drinking taps (for providing to people).

At the moment, the MDWP is set up at a primary school in Danang province, Vietnam. Research group is testing water quality before let the MDWP for real using in the primary school. The input raw drilled water characterization is shown in Table 1. This table shows that the raw drilled well input water characterization is satisfying the standard of livingwater of the Ministry of Health of Vietnam (QCVN 01/2009: BYT).

For being safety drinking water, the raw drilled well water is needed to do disinfection. The water qualities before carrying disinfections by the MDWP are shows in Table 2 and Table 3. Table 2 shows the water quality monitoring during the testing period, from May to July 2019. Table 3 shows the on-site proof of concept at field conditions of the water after disinfection. The results in Table 2 and Table 3 show that water after process with disinfections by MDWP could be used as safety drinking water.

Table 1: Raw Drilled Well Input Water Characterisation

\begin{tabular}{|l|c|c|c|}
\hline \multicolumn{1}{|c|}{ Sample } & Unit & Value & QCVN 01/2009:BYT \\
\hline DOC & $\mathrm{mg} / \mathrm{L}$ & 0,38 & $\mathrm{NA}$ \\
\hline SAC $(254 \mathrm{~nm})$ & $1 / \mathrm{m}$ & 0,5 & $\mathrm{NA}$ \\
\hline $\mathrm{pH}$ & none & 7,2 & $6,5-8,5$ \\
\hline Conductivity & $\mu \mathrm{S} / \mathrm{cm}$ & 298 & $\mathrm{NA}$ \\
\hline Chloride & $\mathrm{mg} / \mathrm{L}$ & 25,9 & 250 \\
\hline Nitrite & $\mathrm{mg} / \mathrm{L}$ & $\mathrm{NA}$ & 3 \\
\hline Nitrate & $\mathrm{mg} / \mathrm{L}$ & 27,5 & 50 \\
\hline Sulphate & $\mathrm{mg} / \mathrm{L}$ & 29,7 & 250 \\
\hline Calcium & $\mathrm{mg} / \mathrm{L}$ & 20,4 & 300 \\
\hline Magnesium & $\mathrm{mg} / \mathrm{L}$ & 12,8 & $\mathrm{NA}$ \\
\hline \multicolumn{2}{|r|}{}
\end{tabular}


Table 2: Water Quality Monitoring during MDWP Testing Period

\begin{tabular}{|l|c|c|c|}
\hline \multirow{2}{*}{ Treated Water } & Escherichia Coli (E. Coli) & Enterococci & QCVN 01/2009:BYT \\
\cline { 2 - 4 } & number/100ml & number/100ml & number/100ml \\
\hline 1st Week May & 0 & 0 & 0 \\
\hline 2nd Week May & 0 & 0 & 0 \\
\hline 3rd Week May & 0 & 0 & 0 \\
\hline 4th Week May & 0 & 0 & 0 \\
\hline 1st Week June & 0 & 0 & 0 \\
\hline 2nd Week June & 0 & 0 & 0 \\
\hline 3rd Week June & 0 & 0 & 0 \\
\hline 4th Week June & 0 & 0 & 0 \\
\hline 1st Week July & 0 & 0 & 0 \\
\hline 2nd Week July & 0 & 0 & 0 \\
\hline 3rd Week July & 0 & 0 & 0 \\
\hline 4th Week July & 0 & 0 & \\
\hline
\end{tabular}

Table 3: On-Site Proof of Concept at Field Conditions

\begin{tabular}{|c|c|c|c|c|c|}
\hline \multirow{2}{*}{ Date } & \multirow{2}{*}{ Water Flow } & \multirow{2}{*}{ UV Transmission } & \multicolumn{3}{|c|}{ Escherichia Coli (E. Coli) } \\
\cline { 4 - 6 } & l/min & Sample 1 & Sample 2 & QCVN 01/2009:BYT \\
\cline { 3 - 5 } & 138,8 & 91,4 & NPN/ml & NPN/ml & NPN/ml \\
\hline Oct. 17th 2019 & 138,8 & 91,4 & 0 & 0 & 0 \\
\hline Oct. 23th 2019 & 166,6 & 93,4 & 0 & 0 & 0 \\
\hline Oct. 27th 2019 & 166,6 & 94,0 & 0 & 0 & 0 \\
\hline Oct. 30th 2019 & 166,6 & 93,6 & 0 & 0 & 0 \\
\hline Nov. 3nd 2019 & 166,6 & 93,9 & 0 & 0 & 0 \\
\hline Nov. 6th 2019 & 160,3 & 92,5 & 0 & 0 & 0 \\
\hline Nov. 10th 2019 & \multicolumn{3}{|l}{} \\
\hline
\end{tabular}

\section{CONCLUSIONS}

In this pare, a design of machine for drinking water processed with hybrid green energy has developed. The hybrid green energy is wind energy and solar energy. Wind energy is provided by a mixture axis wind turbine that developed by the research group. Solar energy is integrated to the wind energy by purchasing solar panels in market.

The MDWP processes raw drilled well input water to safety drinking water by two disinfection devices. They are cell electrochemical and UV disinfections. Testing result shows that the water after processing by the MDWP could be able to use for direct drinking water.

The MDWP is designed with using hybrid green energy. Therefore, the MDWP is suitable for using in removed areas where do not have the national electrical grid. The MDWP is also suitable with the life standard condition in removed areas in Vietnam.

\section{ACKNOWLEDGEMENT}

This research study is funded by the grant numbered B2018-BKA-06SP from Ministry of Education and Training (MOET).

\section{REFERENCES}

1. Government of Vietnam (2012).National strategy on environment protection to 2020 with visions to 2030. Accessible in May 2002

http://www.chinhphu.vn/portal/page/portal/English/strategies/strategiesdetails? categoryId=30\&articleId=10051159. 
2. International Trade Administration (2016).Top Markets Report Environmental Technologies Regional Supplement. Accessible in May 2020 on: http://www.trade.gov/topmarkets/pdf/Environmental_Technologies_Southeast_Asia.pdf

3. Meena Agrawal, Dr, and Arvind Mittal. "Virtual Instrument for Remote Monitoring \& Control of Prototype Hybrid Renewable Energy System." (2015).

4. Asian Development Bank (2015).Viet Nam Urban Environment Program. Urban Sanitation Issues in Viet Nam. Accessible in May 2020 on: https://www.adb.org/sites/default/files/publication/175000/urban-sanitation-issues-vie.pdf

5. Medicine publish house (2007).Sanitation in rural areas in Vietnam.

6. Dogra, Aditya, AkshinaSoni, and YogeeshaPai. "An experimental study on the mechanical properties Of basalt and banana fiber reinforced Hybrid polymer composites." International Journal of Mechanical and Production Engineering Research and Development 9.1 (2019): 263-270.

7. Ministry of Health (2015).Reports on National Strategic Program on Water and Sanitation in rural areas 2011-2015.

8. Bergmann, H. (2008). "Drinking water disinfection by direct electrolysis-state of the art".Proceeding of the CHISA 2008 and 8th European symposium on electrochemical engineering, Prague, pp. 24-28

9. Abrol, Sanchita, and Deepak Chhabra. "Experimental investigations of piezoelectric energy harvesting with turbulent flow." International Journal of Mechanical and Production Engineering Research \& Development 8.1 (2018): 703-710.

10. Song, K., Mohseni, M., Taghipour, F.(2016). "Application of ultraviolet light-emitting diodes (UV-LEDs) for water disinfection: A review”. Water research, 94, pp.341-349.

11. Kansara, BINDU U., and B. R. Parekh. "Penetration of renewable energy resources based dispatch strategies for isolated hybrid systems." Int. J. Electr. Electron. Eng. Res 3 (2013): 121-130.

12. Phan, A. T., Nguyen, M. T. (2018), Development of a Safety Drinking Water Disinfection System for Removed Areas in Vietnam Powered by Wind Energy, Lecture Notes in Civil Engineering, ISSN: 2366-2557, Vol. 18, pp. 580-585. 